\title{
3-Metilkolantren ve bütil hidroksitoluenle uyarılmış rat akciğer dokularında p-53 ekson 8 geni mutasyon analizi
}

\author{
Analysis of p-53exon 8 gene mutations in 3-methylcholanthrene and butylated \\ hydroxytoluene-induced rat lung tissues
}

\author{
Meltem Rüyam Demirkol*, İlhan Sezgin, Ahmet Alim \\ Kanser Erken Teşhis Tarama ve Eğitim Merkezi (Dr. M. R. Demirkol), İl Halk Sağlığı Müdürlüğü, \\ TR-58050 Sivas, Tibbi Genetik Anabilim Dalı (Prof. Dr. İ. Sezgin), Cumhuriyet Üniversitesi Tıp \\ Fakültesi, TR-58140 Sivas, Mikrobiyoloji Anabilim Dalı (Doç. Dr. A. Alim), Cumhuriyet \\ Üniversitesi Veteriner Fakültesi, TR-58140 Sivas
}

\section{Özet}

\begin{abstract}
Amaç. Bu çalışmada, gıda katkı maddesi olarak kullanılan Bütillenmiş hidroksitoluen (BHT)'in sadece kendisinin ve ayrıca BHT'nin bir kimyasal karsinojen olan 3-Metilkolantren (3-MC) ile birlikte uyğulandığında rat akciğerlerindeki karsinojen potansiyelleri ve p53 ekzon 8 geni üzerindeki mutasyon etkisinin incelenmesi amaçlanmıştır. Yöntem. Bu çalışmada 52 erkek rat kullanılmıştır. Deneye alınan birinci gruptaki $\left(D_{1}\right.$ grubu) 15 rata, $6 \mathrm{kez} \mathrm{3-MC} \mathrm{(40} \mathrm{mg/kg/hafa}$ dozda ip yolla) uygulanmıştır. Deneye alınan ikinci gruptaki $\left(\mathrm{D}_{2}\right.$ grubu) 15 rata tek doz $40 \mathrm{mg} / \mathrm{kg}$ 3 -MC ve ardından $6 \mathrm{kez}$ BHT (200 mg/kg/hafta dozda ip yolla) uygulanmıştır. Deneye alınan üçüncü gruptaki ( $D_{3}$ grubu) 12 rata, sadece $6 \mathrm{kez}$ BHT $(200 \mathrm{mg} / \mathrm{kg} / \mathrm{hafta}$ ip yolla) uygulanmıştır. Ayrıca 10 rat'tan oluşan bir kontrol grubu kullanılmıştır. Ratlar 26 hafta beklenildikten sonra servikal dislokasyon ile öldürülmüştür. Akciğerler sintigrafik, radyolojik ve morfolojik olarak değerlendirilmiştir. Bütün grupların akciğer dokusundan DNA izolasyonu yapılmış ve bu DNA'lardan, P53 geni ekson 8 amplifkasyonu Polimeraz Zincir Reaksiyonu (PCR) ürünlerinde Single-Strand Conformation Polimorphism (SSCP) analizi yapılarak, nokta mutasyonu taramasi yapılmıştır. Bulgular. Bu çalışmaların sonucunda radyolojik, sintigrafik, morfolojik ve genetik düzeyde ratların akciğerinde kanser oluşumu tespit edilememiştir. Fakat ratlara kimyasal maddelerin uygulanım yerinde yumuşak doku kaynaklı sarkom gelişimi tespit edilmiştir. Yapılan mutasyon taramasında P53 geni ekson 8'de bir mutasyon bulunamamıştır. Sonuç. Her ne kadar çalışmamızda ratlarda kanser oluşumu tespit edemesekte, uygun doz ve zaman uyumlu 3-MC ve BHT uygulayarak, özellikle tümör oluşumuna duyarlı fare türleri kullanarak çalışmanın uygun olacağı düşünülmüştür.
\end{abstract}

Anahtar sözcükler: Bütillenmiş hidroksitoluen (BHT), P53 geni, rat akciğer dokusu, mutasyon, kanser

\begin{abstract}
Aim. In this study we aimed to detect the carcinogenic effects on lungs of rat and, also the mutation effects on P53 ekzon 8 gene of Butylated hydroxytoluene (BHT) and BHT together with 3-Metilkolantren (3-MC) which is a carcinogenic chemical substance. Method. In this study, 52 male rats were used. 15 rats in the first group $\left(D_{1}\right)$ are administered 3-MC i.p $40 \mathrm{mg} / \mathrm{kg}$ per week during 6 weeks. 15 rats in the second group $\left(\mathrm{D}_{2}\right)$ were given a single dose of 3-MC i.p. $40 \mathrm{mg} / \mathrm{kg}$ and subseguently BHT $200 \mathrm{mg} / \mathrm{kg}$ of body weight per week for 6 weeks. 12 rats in the third group $\left(\mathrm{D}_{3}\right)$ were exposed to BHT $200 \mathrm{mg} / \mathrm{kg}$ of body weight on weekly basis for 6 weeks. 10 rats in Control (c) group were only given corn oil in which both 3-MC and BHT are soluable, for 6 weeks receiving $100 \mu \mathrm{l}$ for each shot. The rats were killed with cervical dislocation at the end of 26 weeks. Lung tisues were evaluated by scintigraphic, radiologic and morphologic methods. DNA isolation was carried out tissues of the lungs followed by Polymerase chain reaction (PCR) amplification for exon 8 of p53 gene. Then, in the PCR products mutational analysis was carried out using Single-Strand Conformation Polimorphism (SSCP) technique. Results. Cancer development has not been detected in lung tissues of the rats that were exposed to 3-MC and BHT. However, it has been found that subcutaneous soft tissue sarcomas were detected at the application site of carcinogens. In p53 gene exon 8 screening, there is no mutation were technique found in the
\end{abstract}


lung tissues of all rats. Conclusion. Although we could not detect any cancer formation in our rats, we think that using appropriate dose and timing of 3-MC and BHT in especially cancer sensitive rats is convenient.

Keywords: Butylated hydroxytoluene (BHT), p53 gen, rat lung tissues, mutation, cancer

Geliş tarihi/Received: 28 Ağustos 2012; Kabul tarihi/Accepted: 11 Ekim 2012

\section{*İletişim adresi:}

Dr. Meltem Ruyam Demirkol, Kanser Erken Teşhis Tarama ve Eğitim Merkezi, İl Halk Sağlığı Müdürlüğü, TR-58050 Sivas, E-posta: meltemruyamdemirkol@hotmail.com

\section{Giriş}

Kanser; Latince "crab” sözlüğünden türetilmiştir ve yengeç gibi tutunduğu yeri bırakmaz anlamındadır [1]. Kanser, günümüzde kardiyovasküler hastalıklardan sonra ikinci s1k rastlanan ölüm nedenidir. Fakat hangi faktör etkili olursa olsun tüm kanser tiplerinin somatik hücrelerindeki mutasyonlar sonucu oluştuğu ve bu mutasyonların da bir seri genin ekspresyonunu etkilediği bilinmektedir [1-3]. Kanser oluşumuna sebep olan ilaç ve diğer kimyasal maddelere kimyasal karsinojen adı verilir. Bu ajanların bazıları başlatıcı, bazıları ise ilerleticidir. Deneysel karsinogenezde; başlatıcı (initatör) ajanı takiben ilerletici (promotör) ajanın uygulanması, kanser oluşturmakta esas teşkil etmektedir. Kimyasal karsinogenezisin deneysel kanıtlanması bu yüzyılın başlarında, deney hayvanlarının derisi üzerine kömür katranı uygulanması sonucu deri kanserlerinin oluştuğunu göstermek suretiyle mümkün olmuştur. Bugün bazı ilaçların, besinler içinde alınan bazı maddelerin ve çevre kirlenmesine yol açan bazı kimyasal ajanların karsinojenik etkisi olduğu bilinmektedir [4, 5]. İnsan karsinogenezinde üç önemli faktör belirlenmiştir: I: Sigara, II: İnfeksiyon ve inflamasyon III: Beslenme ve diyet. Genotoksik ajanların (örn: PAH)'da aynı kromozomal hatalar gibi DNA hasarıyla sonuçlanan gen nokta mutasyonlarına, delesyon ve insersiyonlara, rekombinasyonlara ve yeniden düzenlemelere sebebiyet verdiği açıktır. Örneğin proteinli yiyeceklerin (et-balık) fazla kızartılmasıyla açı̆̆a çıkan heterosiklik aminler; meme, kolon, prostat gibi organlarda tümör oluşumunu indüklerler. Aynı şekilde sigara, insan kanserlerinin \%30'unda etken olarak tespit edilmiştir [6, 7].

P53 geni insanda 17. (248-249 bölgede) kromozomda, farelerde ise 11. kromozomun k1sa kolunda bulunur. Deneysel bulgular p53 proteininin hücre çoğalması ve regülasyonunda önemli rol oynadığını desteklemektedir [8]. P53 tümör süpresör geninde oluşan mutasyonlar, kanser olgularında en sık görülen genetik değişikliklerin başında gelir. P53 gen ürünleri bazı tümörler için süpresör etkiye sahiptir. Bu gen ve bitişik loküsler için heterzigotluk kayb1, süpresör etkiyi inaktive eder ve kolon kanseri, akciğer kanseri, meme kanseri, beyin tümörleri, hepatosellüler karsinom ve kronik myeloid lösemi gibi kanser türlerinin oluşumunda yer alır [2, 9, 10]. Bir antioksidan olan bütillenmiş hidroksitoluen (BHT), özelikle hayvansal gidaların bozulmadan saklanmasında kullanılmaktadır. Kimyasal bir karsinojenin ardından uygulandığında (belli doz- süre ile) kanser oluşturmasına rağmen tek başına karsinojen olmadığı birçok deneyle ispatlanmıştır. Yaklaşık 40'dan fazla ülkede serbestçe kullanılan bu kimyasalın toksik etkileri tartışmalıdır. Araştırmamızda kullanılan 3-Metilkolantren (3-MC) ve bütillenmiş hidroksitoluenin (BHT) ardarda uygulanması ile akciğer kanser oluşum insidansını artırdığı yönünde çalışmalar vardır [6].

Çalışmamızda gıda katkı maddesi olarak kullanılan BHT’nin sadece kendisinin ve ayrıca BHT'nin bir kimyasal karsinojen olan 3-MC ile birlikte uyğulandığında rat akciğer dokularındaki karsinojen potansiyelleri ve P53 ekson 8 geni üzerinde mutasyon etkisinin incelenmesi amaçlanmıştır. 


\section{Gereç ve yöntem}

Çalışmamızda, initatör madde olarak, 3-MC ve promoter olarak da BHT kullanılmıştır. $\mathrm{Bu}$ maddeler tek tek ve ardı ardına olmak üzere üç grup rat oluşturarak uygulanmıştır. $\mathrm{Bu}$ kimyasal ajanların p53 eksen 8 geninde mutasyon oluşturup oluşturmadığını incelemek üzere, deney süresi bitince akciğer dokularından izole edilen DNA'ları öncelikle PCR yöntemiyle amplifiye edilmiştir. Bu çalışmada Cumhuriyet Üniversitesi Tıp Fakültesi Deney Hayvanları Laboratuvarı'ndan temin edilen ratlar (Rattus norvegicus wistar albino) kullanılmıştır. Çalışmada 52 adet erkek, Wistar Albino rat kullanılmıştır. Her biri ortalama 100-110 gr ağırlığında olan denekler; kronik 3-MC (15 adet), 3-MC / BHT (15 adet), kronik BHT (12 adet) ve kontrol grubu (10 adet) olacak şekilde gruplandırılmıştır.

Çalışmada ayrı ayrı ve kombine şekilde 3-MC ve BHT uygulanan ratlar, 26 haftalık bir süreci takiben servikal dislokasyonla öldürülmüş ve akciğer dokularından DNA izolasyonları yapılmıştır. İzole DNA'larda p53 ekson- 8 gen bölgesi PCR ile çoğaltılmış, SSCP yöntemi ile mutasyonlu bölge varlığg araştırılmıştır.

\section{Deney grupları ve dozlar}

1. Grup $\left(D_{1}\right)$ : 15 adet rat kullanılmış ve altı hafta boyunca $40 \mathrm{mg} / \mathrm{kg} / \mathrm{hafta}$ dozda 3metilkolantren intraperitonal (ip) yolla uygulanmıştır.

2. Grup $\left(\mathrm{D}_{2}\right)$ : 15 adet rat kullanılmış ve $40 \mathrm{mg} / \mathrm{kg} 3$-metilkolantren tek doz olarak uygulanmış ve ardından altı hafta boyunca $200 \mathrm{mg} / \mathrm{kg} / \mathrm{hafta}$ bütil hidroksitoluen ip yolla verilmiştir.

3. Grup $\left(D_{3}\right)$ : 12 adet rat kullanılmış ve 6 hafta boyunca $200 \mathrm{mg} / \mathrm{kg} / \mathrm{hafta}$ bütil hidroksitoluen ip yolla uygulanmıştır.

4. Grup (Kontrol grubu): 10 adet rat kullanılmış ve bu grup ratlara altı hafta boyunca haftada bir kez $100 \mu \mathrm{l} / \mathrm{kg} /$ hafta mısır yağı ip yolla enjekte edilmiştir.

Her deney grubunda denekler 26 haftalık bekleme süresinin bitiminde (enjeksiyonların bitmesini takip eden zaman zarfinda), servikal dislokasyon yolu ile öldürülmüştür. Öldürülen ratların göğüs bölgeleri açılarak akciğerleri çıkarılmış ve gerekli işlemlerden geçirilerek DNA izolasyonu yapılmak üzere uygun ortamlara alınmıştır (\%98'lik alkol). Alınan akciğer dokusunun bir kısmı ise akciğerlerde tümör dokusu oluşup oluşmadığını kontrol etmek amacı ile C.Ü. Araştırma ve Uygulama Hastanesi Patoloji Laboratuarına gönderilmiştir. Daha sonra dokulardan DNA izole edilmiş, İzole edilen DNA'lar $50 \mathrm{ng} / \mu \mathrm{l}$ olacak şekilde seyreltilerek, PCR işlemi uygulanmıştır. P53 genine ait uygun primerler kullanılarak yapılan PCR'dan sonra \%1'lik agaroz jelde yürütülmüş ve daha sonra PCR ürünlerine nokta mutasyon analizleri için Single-Strand Conformation Polimorphism (SSCP) yöntemi uygulanmıştır.

\section{Bulgular}

Çalışma süresi boyunca ilk gruptan 6, ikinci ve üçüncü grupda 1'er rat kaybedilmiştir. Deneye alınan ratlar üzerinde yapılan incelemelerde tümör dokusuna rastlanılmamıştır. Ancak kronik 3-MC grubundaki ratlardan 5 tanesinde, enjeksiyon uygulanım alanı yakınlarında mezenkimal kaynaklı yumuşak doku tümörü (rabdomyosarkoma) oluşumu saptanmıştır. Akciğerde yapılan histopatolojik inceleme sonucunda makroskobik ve mikroskobik düzeyde tümör saptanmamıştır. Ancak inceleme sırasında kontrol ve deney gruplarının akciğerlerinde nonspesifik kanama (servikal dislokasyon esnasında oluştuğu düşünülen), seyrek mononükleer hücre infiltrasyonu ve bazı alveollerde atelektazi tespit edilmiştir. Direkt akciğer grafisi çekilerek yapılan radyolojik inceleme sonucunda, deney gruplarının hiçbirinde akciğerde tümör oluşumuna rastlanmamıştır. Bu uygulama sonucunda; ratlara altı hafta boyunca haftada bir kez $40 \mathrm{mg} / \mathrm{kg} \mathrm{MC}$ enjekte edilen grupta hiçbir mutasyona rastlanmamıştır. Tümör oluşumunu indüleyici olarak tek doz $\mathrm{MC}$ ve promote edici ajan olarak altı kez BHT uygulanan grupta ve kronik BHT grubunda da yine herhangi bir P53 ekson 8 geni mutasyonu bulunamamıştır.

PCR işleminden sonra mutasyon araştırılması için amplifiye edilen 155 baz çiftlik p53 
ekson 8 gen bölgelerinde, mutasyon tespitinde SSCP tekniğini kullanılmıştır. Yapılan SSCP'lerde normalin dışında bir bant oluşumu gözlenmemiştir. Bunun neticesinde DNA dizi analizine gerek görülmemiştir.

\section{Tartışma}

Kanser, kordiyovasküler sistem hastalıklarından sonra ikinci en sık ölüm nedeni olması bakımından deneysel çalışmalarda ilgi odağı haline gelmiştir. Birçok kanserin oluşumunda çevresel faktörler ve yaşam tarzının etkisi, yapılan çalışmalarla ispat edilmiştir [11]. Finlandiya'da yapılan bir araştırmada Vakahangas ve ark. [12], akciğer kanserleriyle yakından ilgili bulunan p53 gen mutasyonlarının yalnızca sigara içenlerde değil pasif sigara dumanına maruz kalan kadınların tümörlerinde de bulunduğunu göstermiş̦tir. G:C $\rightarrow$ A:T transisyonları 28 akciğer tümörlü hastanın 11'inde (\%39) bulunmuş ve bunların hayatları boyunca sigara içmemiş kadınların akciğer tümörlerinde olduğu ispatlanmıştır. Farklı bir çalışmada ise 24 sigara içmeyen fakat tümörlerinin kömür dumanına maruz kalmakla ilişkisi olan hastaların akciğer tümörlerinde, p53 ve Kiras mutasyonları bulunmuştur. $\mathrm{G} \rightarrow \mathrm{T}$ transversiyonları Ki-ras'da \%86, p53'de \%76 oranında tespit edilirken; p53 (\%33)'ün 153-158 kodonlarının guanince zengin kodonlar olduğu ve nontrans kribe zincirde guaninlerin \%100'ünün $\mathrm{G} \rightarrow \mathrm{T}$ transversiyonlara sahip olduğu belirtilmiştir [13]. Bu mutasyon spektrumu, kömür dumanının birincil komponenti olan PAH'lara maruz kalma ile alakalıdır. Bu sonuçlar gösteriyor ki p53 ve Ki-ras genlerindeki mutasyonlar, spesifleks bir çevresel maruziyeti yansitabilmelidir [13]. P53 tümör süpresör genindeki mutasyonlar, insan kanserlerinin bir çoğunda en sık görülen başkalaşımlardır. P53 proteini, hücrenin genomik bütünlüğünün devamında önemli rol oynamakta ve DNA hasarına yanıt olarak; ya hücre siklusunu G1 fazında durdurmakta veya hücreyi apopitozise sürüklemektedir. Bu gen bölgesindeki herhangi bir mutasyon oluşumu, allel kaybı, kanser gelişimindeki esas anormalliklerin başında gelir. Dünyada, kanserden ölüm sebeplerinde birinci sırayı alan akciğer kanserlerinde de aynı durum büyük çoğunlukla karşımıza çıkmaktadır. P53 gen mutasyonlarının tespit edildiği akciğer kanserlerinde SSLC (küçük hücreli akciğer kanseri) tiplemesi yaygın olarak saptanmıştır [14]. P53 mutasyonları kimi araştırıcılara göre bir tümör gelişiminin erken evresinde oluşmakta ve bir tümör markeri gibi düşünülebilmektedir. Çoğu kez de kötü prognozu göstermektedir. Bazı araştırıcılar ise, tümörler makroskobik görülmeye başladıktan sonra p53 mutasyonlarını tespit etmişlerdir [15-18]. Akciğerlerin, dış çevre ile en çok etkileşen organ olması sebebiyle hava kirliliğinden maksimum zarar görmesi kaçınılmazdır. 3-MC, Kirli kent havasında yüksek oranda bulunduğundan, birincil olarak akciğerlere zarar vermektedir. Yapılan bazı çalışmalar, 3-MC'in tek başına tümör oluşturmakta yetersiz olduğunu ve sadece tümörün başlangıç aşamasını indükleyebileceğini, tümör gelişimi için BHT gibi promotör bir madde uygulanması gerektiğinden bahsetmektedir. Malkinson ve ark. [19]'nın Balb-c fareleri üzerinde yaptığı deneye göre; tek doz $10 \mathrm{mg} / \mathrm{kg} 3-\mathrm{MC}$ ve ardından 6 hafta boyunca $200 \mathrm{mg} / \mathrm{kg}$ kronik BHT uygulanan denek grubu ile sadece tek doz $15 \mathrm{mg} / \mathrm{kg}$ 3-MC verilen grup arasında yapılan karşılaştırma sonucunda; 3-MC ve BHT'nin ard arda kullanıldığı ilk grupta akciğer tümörlerinin sayısında 12-26 kez artış tespit edilmiştir. Aynı araştırıcılar, bu maddelerin tümör oluşumuna duyarlı fare soylarında tümör çeşitliliğini artırdığını göstermişlerdir. Bu çalışmamızda Wisatar Rat albino tipi ratlar kullanılmıştır. Hem immunokompetant A/J faresi, hem de Balb-c nüde faresi, deneysel olarak uyarılmış ve doğal olarak oluşmuş akciğer kanseri gelişimine hassastır. Bu sebeple deneysel karsiogenez çalışmalarında sık olarak kullanılmıştır. Ancak; bu özel fare türlerinin bakımı için gerekli laminar akım kabinleri ve bakım gereçlerinin bulunmaması, Wistar Rat albino tipi ratların elde edilmesi ve bakım kolaylığı, bizim bu türü seçmemizde sebep teşkil etmektedir [3, 20].

Kimyasal karsinogenezde kullanılan ajanlardan 3-MC; bakterilere mutajenik, kemik iliğine klastojenik olup, hayvanlarda DNA eklentisini uyardığ bildirilmiştir [21-23]. Cyp450 gen ekspresyonunu artırarak kanser gelişiminde rol oynadığı bilinmektedir. Yapılan in vivo bir araştırmada 3-MC'nin tek bir intraperitoneal dozunun $(40 \mathrm{mg} / \mathrm{kg}) 6$ saatte Cyp 
1A gen transkripsiyon oranında $179 \mathrm{kez}$ artışa neden olduğu, Cyp 2c11 geni transkripsiyon oranında kontrolle karşılaştırıldığında \%51 civarında redüklenmiş olduğu gösterilmiştir. Ayrıca MC’nin ratlardaki yarılanma ömrünün 16 saat olabileceği not edilmiştir [24].

Çalışmamızda 3-MC, $40 \mathrm{mg} / \mathrm{kg} /$ hafta şeklinde 6 hafta boyunca intra peritoneal (i.p.) olarak 15 adet erkek rata uygulanmıştır. Deneysel çalışmanın yapıldığ 1 birinci grupta $\left(D_{1}\right.$ grubu) 26 haftalık bekleme süresinin sonunda, sağ kalan 9 rattan 5'inde, enjeksiyon bölgesine yakın yerleşimli, mezenkimal kaynaklı yumuşak doku tümörleri (rabdomyosarkoma) tesbit edilmiştir. Bu sonuç doğrultusunda 3-MC'nin bu dozda, yumuşak doku tümörlerinin oluşumunda hem initatör hem de promotör rol oynadığı söylenebilir. $\mathrm{D}_{1}$ grubunda yapılan radyolojik ve histopotojik inceleme sonucunda, akciğerlerde makroskopik ve mikroskobik düzeyde tümör oluşumuna rastlanmamıştır. $\mathrm{Bu}$ grubun sintigrafi sonuçları da her hangi bir patolojik izlenim göstermemiştir. Akciğer dokusunda P53-ekson-8 pen bölgesinde (SSCP tekniği kullanılarak) mutasyonun gözlenmemesi 3-MC uygulamasının zaman ve doz açısından yetersiz olduğunu düşündürmektedir. $\mathrm{D}_{1}$ grubunda ölümlerin fazla görülmesi, soğuk hava ve laboratuvar şartlarına, MC'in metabolizmadaki olumsuz etkilerine bağlanmıştır. Bu gruptan 6 rat'ın ölmesi bekleme süresinin 26 haftayı geçmemesine neden olmuştur. Akciğerlerdeki nonspesifik kanama olanları ve seyrek mononükleer hücre infiltrasyonu; diğer gruplarda da görüldüğünden, ratların öldürülme şeklinden kaynaklanabileceği kanısına varılmıştır. 1998'de yapılan bir çalışmada; 63 adet MC ile indüklenmiş fare sarkmalarının genomik DNA'lar1 P53 geninin ekson 5, 6, 7 ve 8. bölgeleri üzerinde PCR ve SSCP analizi ile yapılan incelemelerde P53 mutasyonu tespit edilmiştir. Çoğunluk G:C $\rightarrow$ T:A transversiyonu şeklinde olan mutasyonlardır ve 172, 342, 245, 246, 270 ve 279 . kodonda gözlenmişlerdir. P53 mutasyonlarına benzer $\mathrm{G}: \mathrm{C} \rightarrow \mathrm{T}: \mathrm{A}$ trensversiyonlu ki-ras mutasyonlarının eşlik etmesi, MC ile oluşan mutasyon spektrumunun, P53 ve ki-ras geni için benzer olduğunu göstermiştir [9]. Aynı araştırmacılar, bu mutasyonların c-myc geni amplifikasyon artışıla birlikteliğini ispatlamışlardır [25].

Bu çalışmada 3-MC ile birlikte ve tek başına kullanılan BHT, özelikle hayvansal gidaların bozulmadan saklanmasında kullanılan bir antioksidandır. Bir kimyasal karsinojenin ardından uygulandığında (belli doz- süre ile) kanser oluşturmasına rağmen

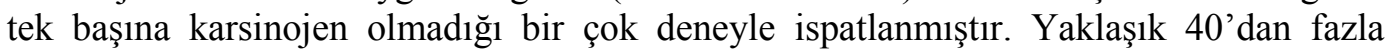
ülkede serbestçe kullanılan bu kimyasalın toksik etkileri tartışmalıdır. Yapılan araştırmalarda BHT, düşük dozlarda bakterilerde mutasyona neden olmamıştır. Farelerde dominant mutasyonları uyarmadığ edilmiştir. Fakat Çin Hamster V 79 hücrelerinde mutajenik olduğu, BHT’ye maruz kalmış ratların karaciğerlerinde DNA'ya bağlandığı ancak hiçbir eklenti oluşturma etkisi saptanmamıştır [26]. Kronik BHT grubumuzda, mutasyon bazında herhangi bir tümör oluşumuna rastlanmamasını, bu maddenin karsinogenezde promotör ajan olarak rol almasına, ratların bu maddeye tolerans geliştirmesine ya da direnç kazanmalarına bağlayabiliriz. Witchi ve Morse [27], yaptıkları araştırma ile BHT'nin tekrarlanmış enjeksiyonlarından sonra farelerde tolerans gelişebileceğini göstermişlerdir. $300 \mathrm{mg} / \mathrm{kg}$ dozunda $5 \mathrm{kez}$ BHT enjeksiyonunu takiben farelerin bu maddeye dirençli hale geldiği tespit edilmiştir. BHT'nin tek doz enjeksiyonunun akciğerde özellikle tip II alveolar epitel hücrelerinde belirgin bir hücre proliferasyonuna neden olduğu, ikinci BHT uygulamasının çok az bir yanıt meydana getireceğini ve üçüncü BHT enjeksiyonundan sonra akciğerde herhangi bir başka hücre hiperplazisi üretmenin mümkün olamayacağını saptamışlardır. Bu da BHT'nin hücresel ve humoral bağışıklık sistemleri üzerinden etkisini gerçekleştirdiğini desteklemektedir [25].

Çalışmamızda 3-MC; initatör olarak, BHT ise promotör olarak kullanılmıştır. Bu iki maddenin ard arda kullanımının, kanser oluşumunu değişik oranlarda artırdığına dair bir çok çalışma vardır. Malkinson ve ark.[28]'nın yapmış olduğu bir çalışmada tek doz MC uygulamasından sonra 6 hafta süreyle BHT enjeksiyonu ile tümör insidansının artacağı 
gösterilmiştir [28]. İkili karsinogenezise örnek olabilecek farklı bir çalışmada ise $\mathrm{BALB} / \mathrm{C}$ farelerine gebeliğin 17. gününde $\mathrm{MC} 5,15$ ve $45 \mathrm{mg} / \mathrm{kg}$ dozunda enjekte edilmiş, doğumdan sonra ise 6 hafta boyunca $200 \mathrm{mg} / \mathrm{kg}$ BHT i.p. olarak uygulandiktan sonra fareler, 6 aylıkken öldürülmüştür. Deneylerde BHT'nin kronik inflamutuar cevabı indüklediği, hücreler arası iletişimi bozduğu, normal hücrelerde apopitozisi uyardığı ve böylece tümör gelişimini artırdığı savunulmuştur. Burada MC'in transplasental karsinojenik etki göstermekte olduğu da vurgulanmıştır. $\mathrm{Bu}$ da bize daha anne karnındayken karşılaşılan kimyasalların, doğumdan sonra ne derece önem kazandığını göstermektedir [23].

Bu çalışmada $40 \mathrm{mg} / \mathrm{kg}$ tek doz MC enjeksiyonunu takiben 6 hafta $200 \mathrm{mg} / \mathrm{kg} / \mathrm{hafta}$ dozunda BHT uygulanmıştır. Deneye alınan ikinci gruptaki $\left(\mathrm{D}_{2}\right)$ bu ratların akciğerlerinde hiperplazi dahil hiçbir tümör öncesi lezyona rastlanmamıştır. 3-MC'yi takiben kullanılan BHT'nin akciğerde herhangi bir patolojiye sebep olmaması, yeterli dozlara ve bekleme süresine ulaşılamaması ile açılanabilir. Her ne kadar P53 gen mutasyonlarının, kanser türlerinin de erken evrelerde tespit edilebileceği gösterilmişse de; farede akciğer tümörlerinin gelişimi için öngörülen skalaya göre ancak 32. hafta ve sonrasında RB, P53, MTS1 gibi tümör süpresör gen mutasyon ve delesyonu gerçekleşmektedir [28]. Sonuç olarak;

1. Akciğer kanserinde $\% 56$ gibi yüksek oranda tespit edilen p53 gen mutasyonu, 40 $\mathrm{mg} / \mathrm{kg}$ MC ve $200 \mathrm{mg} / \mathrm{kg}$ BHT dozlarının ayrı ayrı ve bir arada uygulandığı üç farklı rat grubunda da izlenmemiştir. BHT ya da MC daha yüksek dozda uygulansaydı, akciğerde tümör oluşumu daha erken bir safhada tespit edilebilirdi.

2. Denek olarak kullandığımız Wistar Albino ratların kimyasallar için dirençli olduğu bilinmektedir. Bunların yerine Balb-c, A/J, immunokompetent fareler kullanılsaydı, daha erken haftalarda aynı dozlarda tümör oluşturulabilirdi. Ancak laboratuvar şartlarının uygunsuzluğu, tümör oluşumuna duyarlı fare türlerinin yetiştirilip kullanılmasına olarak sağlamadığından, wistar albino ratlar tercih edilmiştir.

3. Her ne kadar 26 haftalık bekleme sürecinde akciğer tümör gelişimine ait bir bulguya rastlanmamış olsa da; devamlı olarak iç içe yaşadığımız çevre koşulları, kirli kent havasındaki PAH'lar, hazır gidalara talebin artmasıyla otomatikman vücudumuza giren antioksidanlar; yaşantımızın ileri döneminde kanser için bir risk oluşturmaktadır. Doğallıktan uzaklaşıp, teknolojiyi hayatı kolaylaştırmak için dikkatsizce ve fazlaca kullanan insanlar; bunun kendileri için nasıl bir gelecek hazırlandığının farkında değildirler.

\section{Kaynaklar}

1. Kumar V, Cotran R, Robbins S. Temel Patoloji (Çeviri). Çev. ed. Çevikbaş U. İstanbul, Nobel Tip Kitabevi, 2000; pp: 133-74.

2. Başaran N. Tıbbı Genetik (6. Baskı). Bilim ve Teknik Yayınevi, İstanbul, 1996.

3. Çolak A, Pınarbaşı E. Tıbbı Biyoloji. Cumhuriyet Üniversitesi Yayınları. Sivas, 1994; 57: 185-8.

4. Kayaalp O. Tibbi Farmakaloji, Güneş Kitabevi, Ankara, 1994; I: 303-85.

5. Yenerman M. ed. Genel Patoloji. Nobel Tip Kitabevi, İstanbul, 1994; 1362-77.

6. Brown LM, Malkinson AM, Rannels DE, Rannels SR. Compensatory lung growth after partial pneumonectomy enhances lung tumorigenesis induced by 3 methylcholanthrene. Canter Res 1999; 59: 5089-92.

7. Yenerman M. ed. Genel Patoloji. Nobel Tip Kitabevi, İstanbul 1994; 1362-77.

8. Sezgin İ. Klinik Genetik, Cumhuriyet Üniversitesi Yayınları, Sivas 1998; 70: 221-5.

9. Shimokado K, Watanabe H, Sumii M, Miyagawa K, Kamiya K, Dohi K, Niwa O. p53 gene mutation and loss of heterozygosity of chromosome 11 in methylcholanthrene-induced mouse sarcomas. Jpn J Cancer Res 1998; 89: 26977. 
10. Macdonald F, Ford CHJ. Oncogenes and Tumor Supressor Genes. BIOS Scientific Publishers Limited, Printed by İnformation Pres Ltd, Oxford, U.K., 1991.

11. Ruddon RW. Cancer Biology. Oxford University Press. 236, Newyork, Oxford 1995.

12. Vähäkangas KH, Bennett WP, Castrén K, Welsh JA, Khan MA, Blömeke B, Alavanja MC, Harris CC. p53 and K-ras mutations in lung cancers from former and never-smoking women. Cancer Res 2001; 61: 4350-6.

13. DeMarini DM, Landi S, Tian D, Hanley NM, Li X, Hu F, Roop BC, Mass MJ, Keohavong P, Gao W, Olivier M, Hainaut P, Mumford JL Lung tumor KRAS and TP53 mutations in nonsmokers reflect exposure to PAH-rich coal combustion emissions. Cancer Res 2001; 61: 6679-81.

14. Malory M, Nelkin B, Baylin S. Euolutionary Model of lung Cancer Lung Cancer: Principles and Practice, Philadelphia, 1996.

15. Rollins LA, Leone-Kabler S, O'Sullivan MG, Miller MS. Role of tumor suppressor genes in transplacental lung carcinogenesis. Mol Carcinog 1998; 21 : 177-84.

16. Horio Y, Chen A, Rice P, Roth JA, Malkinson AM, Schrump DS. Ki-ras and p53 mutations are early and late events, respectively, in urethane-induced pulmonary carcinogenesis in A/J mice. Mol Carcinog 1996; 17: 217-23.

17. Yuspa SH. Overview of carcinogenesis: past, present and future. Carcinogenesis 2000; 21: 341-4.

18. Li ZH, Zheng J, Weiss LM, Shibata D. c-k-ras and p53 mutations occur very early in adenocarcinoma of the lung. Am J of Pethol 1994; 144: 303-9.

19. Malkinson AM, Koski KM, Evans WA, Festing MF. Butylated hydroxytoluene exposure is necessary to induce lung tumors in BALB mice treated with 3methylcholanthrene. Cancer Res 1997; 57: 2832-4.

20. Balmain A, Harris CC. Carcinogenesis in mouse and human cells: parallels and paradoxes. Carcinogenesis 2000; 21: 371-7.

21. Rihn BH, Bottin MC, Coulais C, Rouget R, Monhoven N, Baranowski W, Edorh A, Keith G. Genotoxicity of 3-methylcholanthrene in liver of transgenic big Blue mice. Environ Mol Mutagen 2000; 36: 266-73.

22. Niwa O, Kamiya K, Furihata C, Nitta Y, Wang Z, Fan YJ, Ninomiya Y, Kotomura N, Numoto M, Kominami R. Association of minisatellite instability with c-myc amplification and K-ras mutation in methylcholanthrene-induced mouse sarcomas. Cancer Res 1995; 55: 5670-6.

23. Gressani KM, Leone-Kabler S, O'Sullivan MG, Case LD, Malkinson AM, Miller MS. Strain-dependent lung tumor formation in mice transplacentally exposed to 3-methylcholanthrene and post-natally exposed to butylated hydroxytoluene. Carcinogenesis 1999; 20: 2159-65.

24. Lee C, Riddick DS. Transcriptional suppression of cytochrome P450 2C11 gene expression by 3-methylcholanthrene. Biochem Pharmacol 2000; 59: 1417-23.

25. Watanabe H, Shimokado K, Asahara T, Dohi K, Niwa O. Analysis of the c-myc, K-ras and p53 genes in methylcholanthrene-induced mouse sarcomas. Jpn J Cancer Res 1999; 90: 40-7.

26. Williams GM, Iatropoulos MJ, Whysner J. Safety assessment of butylated hydroxyanisole and butylated hydroxytoluene as antioxidant food additives. Food Chem Toxicol 1999; 37: 1027-38.

27. Witschi HP, Morse CC. Cell kinetics in mouse lung following administration of carcinogens and butylated hydroxytoluene. Toxicol Appl Pharmacol 1985; 78: 464-72.

28. Malkinson AM, Belinsky SA. Lung Canner, Lippincott-Raven Publishers, Philadelphia 1996; 273-83. 